\title{
Effect of particle properties on free falling powder jet
}

03401

発表学会名 The $2^{\text {nd }}$ Asian Particle Technology Symposium 2003 (APT2003)

開催 場 所 Penang, Malaysia

開催 期 間２003年12月17日～19日

発 表 者 大島商船高等専門学校 電子機械工学科 助手 尾 形 公一郎

\section{発表の概要}

ホッパー底部の孔から排出される粉体のハンドリン グ操作は空気輸送，化学プラントなどの様々な分野で 用いられている。発表者らは, 現在, 孔から自由落下 する粉体の落下速度に注目して研究を行っている。こ の流れ場は, 容器壁の拘束がなく, 粒子群と気流の運 動のみで形成されるため, 粒子群一流体間相互作用の 基礎研究として興味深いものであるといえる。今回, 発表者らは, 自由落下する粉体の落下速度に及ぼす巻 込み空気や粒子群の数密度, 粒子に作用する力の影響 を数值計算によって調査した。この結果, 粉体の落下 速度が(1)落下距離の小さい場所では，流体抵抗を無 視した単一粒子の落下速度にほほ等しいことや (2)落 下距離が大きくなると落下速度は最大值を示し，その 後, 単一粒子の沈降速度に近づくことを明らかにした。 これらは以前の実験結果を定性的に表現できたといえ る。また，本計算によると，粉体の落下速度の減速に は，粒子と気流の相対速度に基づく，粒子群に作用す る負の加速度が影響することが分かった。さらに，3 種類の粒子径を用いた結果から, 沈降速度に対する粉 体の落下速度の比は，粒子径が小さいものほど増加す ることが明らかとなった。これには粉体の落下運動に より誘起された気流速度や粒子群の数密度, 流体抵抗 の増加が大きく影響することを示した。

\section{学会の概要}

2003年12月16日～18日の日程でマレーシアのペナン 島で第 2 回アジア粉体工学シンポジウムが開催され た。会場はマレーシアでも指折りのリゾートに数えら れるバトゥ・フェリンギ地区のビーチ沿いに位置する パークロイヤルリゾートで行われた。セッションは 「Particle Design, New Technologies and Industrial Application $\rfloor\lceil$ Solid-Fluid Separation Process $\rfloor$ $\lceil$ Particle \& Bulk Powder Characterization」「Powder Handling and Multiphase Flow」の 4 つに分かれてお り，発表者は「Powder Handling and Multiphase Flow」 にて研究発表を行った。特に，アジアからの参加者が 多く，粒子材料生成から粉体ハンドリングまで非常に 多岐に渡る発表が行われていた。特に，発表者の研究 領域に近い粒子間，粒子-流体間相互作用に関する研 究で, 付着力や静電気力など粉体流動を支配するモデ ルの活用・評価など興味深い話題が多く見られ，今後 の研究に対して大いに役立つ情報を得ることができ た。最後に，このような貴重な機会を与えて頂きまし たホソカワ粉体工学振興財団ならびに理事長を始め関 係者の皆様方に深く感謝の意を表します。 